\title{
Impact of wheat straw biochar on yield of rice and some properties of Psammaquent and Plinthudult
}

\author{
Niaz Muhammad ${ }^{1,2}$, Rukhsanda Aziz ${ }^{3}$, Philip C. Brookes ${ }^{1}$, Jianming Xu ${ }^{1 *}$ \\ Institute of Soil and Water Resources and Environmental Science, Zhejiang Provincial Key Laboratory of \\ Subtropical Soil and Plant Nutrition, Zhejiang University, Hangzhou 310058, China. ${ }^{2}$ Department of Microbiology \\ Kohat University of Science and Technology, Kohat 26000, Pakistan. ${ }^{3}$ Department of Environmental Sciences, \\ International Islamic University Islamabad 44000, Pakistan. *Corresponding author: jmxu@zju.edu.cn
}

\begin{abstract}
Agricultural organic matter is a major component of organic waste on earth that significantly contributes in environmental pollution. The conversion of organic waste into biochar and addition to soil is the recommended strategy to reduce the negative environmental effects of organic waste and to increase the soil fertility. Therefore, in this study, we evaluated the changes in nutrient concentrations, rice yield and microbial community structure in a Psammaquent and Plinthudult at harvest following incorporation of biochar derived from wheat straw. Wheat straw biochar generated at $300-500{ }^{\circ} \mathrm{C}$ under oxygen limited conditions was applied, in a greenhouse experiment to a Psammaquent and Plinthudult at a rate of 3\% weight/weight (w/w). The biochar addition to both types of soil significantly increased the soil $\mathrm{pH}$ from 4.2 to 6.2 and 4.7 to 6.7 , total nitrogen by 135 and $37 \%$, and organic carbon by 90 and 80\%, in the Psammaquent and Plinthudult, respectively as compared to the respective controls. The dissolved organic nitrogen (DON) was decreased by 24 and $15 \%$ and dissolved organic carbon (DOC) by 40 and $44 \%$ in Psammaquent and Plinthudult, respectively. The biochar decreased the concentrations of K leached by $24 \%$, B by $25 \%$, Cu by $80 \%$, Mn by $37 \%$ and $\mathrm{Zn}$ by $33 \%$ in the Psammaquent and B by $50 \%$, Cu by $60 \%$, Fe by $43 \%$, Mn by $69 \%$ and $\mathrm{Zn}$ by $83 \%$ in the Plinthudult as compared to the controls. The wheat straw biochar addition to two soils increased the accumulation of $\mathrm{Mn}, \mathrm{Mo}, \mathrm{Na}$ and $\mathrm{Zn}$ in both rice straw and grain and decreased the leaching of nutrients, organic carbon and nitrogen at rice harvest and increased the leaching of $\mathrm{Ca}, \mathrm{Na}$, and Mg in both Psammaquent and Plinthudult. The biochar increased the $\mathrm{pH}$, TOC and nitrogen in both soils. The biochar significantly changed the PLFA concentration indicating different microbial community pattern in soils growing rice compared to their controls. Thus, the results indicated that wheat straw biochar increased the productivity of rice in the Plinthudult and Psammaquent.
\end{abstract}

Keywords: Wheat straw biochar, Psammaquent, Plinthudult, rice yield, microbial community structure 


\section{Introduction}

Rice is the staple food for more than $65 \%$ of the population in China. Its production has increased several folds in the past few decades (Huang et al., 2013). The increasing population is exerting a huge pressure for improved food production in China (Zhang et al., 2010). The poor soil quality has been a major hindrance in higher rice yield in China. To overcome this issue more agriculture land is required. Red soil is abundantly available in China and can be used for this purpose. The red soils cover 102 million ha in China and can be used for agriculture purposes. These soils have great potential for agriculture due to favorable climatic conditions.

Biochar incorporation into agricultural soils has recently stimulated much scientific research due to its agronomic, financial, and ecological benefits. Biochar is a carbon $(\mathrm{C})$ rich material produced by pyrolysis of feedstock at different temperatures under oxygen limiting conditions (Cao et al., 2011; Khan et al., 2013; Uchimiya et al., 2011). Feedstocks, which are readily available in large quantities and have no other uses, are suitable materials for biochar production. Many types of feedstock are used for biochar production, including wood, corn stover, rice straw, rice husks, bamboo, wheat straw, peanut shells, poultry litter, and animal manures (Gul et al., 2015; Khan et al., 2013; Meng et al., 2013; Zhang et al., 2010). Biochars are resistant to microbial degradation, releasing only small amounts of $\mathrm{CO}_{2}$ to the atmosphere and thereby increasing $\mathrm{C}$ sequestration (Bruun et al., 2012; Cheng et al., 2008; Zhao et al., 2014). Biochars have a higher negatively charged surface area than their original feedstock or soil (Khan et al., 2013). The addition of biochar to soil increases nutrient concentrations, adsorption of elements onto its surfaces, and increases the cation exchange capacity, $\mathrm{pH}$, water holding capacity, and decreases soil bulk density (Zhang et al., 2010; Keith et al., 2011; Khan et al., 2013; Muhammad et al., 2016). The addition of biochars to sandy soils induced significant changes in microbial community structure and soil fertility (Ameloot et al., 2013; Muhammad et al., 2016). Biochars, derived from various feedstocks, applied to sandy loam soil also significantly increased soil $\mathrm{pH}$, dissolved and total organic $\mathrm{C}$ and $\mathrm{N}$, in soil and soil solution and changed the microbial community structure (Muhammad et al., 2014). Different types of biochars have been used in greenhouse experiments and field trials to study their effects on greenhouse gases emission and soil quality.

Biochar has been reported to improve soil quality and crop productivity in different agricultural soils (Huang et al., 2013). There are various mechanisms involved in the enhancement of crop productivity in biochar amended soils. For instance, the dark color of biochar amended soils modifies the thermal dynamics, consequently increasing crop growth and biomass. Wheat straw biochar in saline soils reduced the mineralization of soil organic C (Junna et al., 2014) and in paddy soils increased $\mathrm{C}$ sequestration, fertility and also reduced unwanted emissions to the environment (Zhao et al., 2014). Wheat straw is an agricultural waste in China and has been used in various types of soil as biochar for soil improvement and carbon sequestration. Red soils are not fertile as they have low $\mathrm{pH}$, extremely leached, low in organic matter, poor in nutrients and have low water holding capacities. In recent times, efforts have been made mainly in the context of the "Great Leap Forward" to bring these red soils into agricultural practices. However, efforts have been ineffective and could not sustained arable agriculture due to their erodibility. The biochar increases nutrient concentrations cation exchange capacity, soil organic matter, $\mathrm{pH}$, water holding capacity, and decreases soil bulk density (Keith et al., 2011; 
Khan et al., 2013; Zhang et al., 2010). Therefore, the aim of this experiment was to evaluate the impact of wheat straw biochar on Psammaquent and Plinthudult for the improvement of fertility, yield of rice and the microbial community pattern in these soils.

\section{Materials and Methods}

\subsection{Soils and biochar}

The Psammaquent and Plinthudult were collected from the Zhejiang province of China, as composites of individual cores (0-10 cm depth), as described by Wu et al. (2009a). Obvious vegetation, roots and stones were removed, and the soils then air-dried and sieved $<2 \mathrm{~mm}$. Sub samples were taken for physical and chemical analyses. The wheat straw biochar was purchased from Sanli Company, Shandong, China. This biochar was generated at $300-500{ }^{\circ} \mathrm{C}$ under oxygen limited condition.

\subsection{Greenhouse experiment}

Rice (Oryza sativa L. var. Zhongzheyou) was grown in plastic pots, of $20 \mathrm{~cm}$ diameter and $20 \mathrm{~cm}$ height, each containing $5 \mathrm{~kg}$ air dried sieved soil, in greenhouse under controlled environmental conditions (16 h light at $30{ }^{\circ} \mathrm{C}$ and $8 \mathrm{~h}$ dark at $22{ }^{\circ} \mathrm{C}$ ) at Zhejiang University, Hangzhou, P.R China. The rice cultivar was an annual Indica variety with an average plant height of $120 \mathrm{~cm}$ at maturity (about 140 days). Seeds were obtained from the Zhejiang Seed Co. They were surface sterilized in 70 percent ethanol for $1 \mathrm{~min}$ and then soaked in $0.01 \mathrm{~g}$ $\mathrm{mL}^{-1}$ sodium hypochlorite for $5 \mathrm{~min}$, rinsed thoroughly in deionized water, and then maintained in deionized water for $48 \mathrm{~h}$ at $30{ }^{\circ} \mathrm{C}$ (Wu et al., 2011). They were then germinated in quartz sand, previously washed with 5 percent $(\mathrm{v} / \mathrm{v}) \mathrm{HCl}$. Biochar at $3 \% \mathrm{w} / \mathrm{w}$ was added to the soils as earlier works by Dai and Muhammad et al. (2014) had indicated improvement in soil fertility at that application rate. The biochar was fully mixed in the pots. Rice seedlings, at about 30 days of growth, were transplanted into the plastic pots. Control treatments without biochar were also included. All the treatments were in triplicate $(n=3)$ with a completely randomized design. Rice was grown under continuously flooded and water logged conditions with an approximately $2-4 \mathrm{~cm}$ water head in each pot until harvesting. Fertilizers were applied (per pot) as basal dressings at the rates of $0.5 \mathrm{~g} \mathrm{~N}$ as $\left(\mathrm{NH}_{4}\right)_{2} \mathrm{SO}_{4}, 53.3 \mathrm{mg}$ of $\mathrm{P}$ as $\mathrm{KH}_{2} \mathrm{PO}_{4}$, and $267 \mathrm{mg}$ of $\mathrm{K}$ as $\mathrm{K}_{2} \mathrm{SO}_{4}$. A second surface application of ammonium sulfate as a top dressing was also given at $0.5 \mathrm{~g}$ $\mathrm{N}$ per pot on the 60 days after transplanting.

Plant growth measurements (i.e. plant height, leaf length and width and grain yield) were taken every week after the 30 days of transplanting. Plant height was measured from stem base to the plant tips. Leaf length was measured from the same fixed nodes and the width at the center of the leaves at each measurement time.

Soils, plant and leachates were collected at harvest after 120 days of transplantation. The leachates were obtained by a slightly modified technique of Karami et al. (2011). Tubes were attached to large plastic tips by paraffin film. Small holes were made at the tips. The punctured tips were inserted near the base of the pots by making a small hole and tilted at 60 degrees to collect the leachate from each pot (Figure 2). Soils and test crop from each pot were collected separately and air dried before analysis. 


\subsection{Analyses}

The soils and biochar were analyzed before the experiment and biochar amended and un-amended soils growing rice at harvesting time. The soil samples were thoroughly mixed, air-dried and sieved $<2 \mathrm{~mm}$ before analysis. The $\mathrm{pH}$ was measured at a 1:2.5 (soil or biochar:water) ratio with a $\mathrm{pH}$ meter. Clay, silt and sand contents were determined by a hydrometric method. The DOC and DON were extracted from 2 $\mathrm{g}$ of each soil, after shaking with $20 \mathrm{~mL}$ of distilled water in $50 \mathrm{~mL}$ polypropylene bottles on a reciprocating shaker at $200 \mathrm{rev} \mathrm{min}^{-1}$ for $1 \mathrm{~h}$. The soil extracts were then centrifuged at $4000 \mathrm{~g}$ for $10 \mathrm{~min}$. The DOC and DON were determined in the supernatants, using a Shimadzu TOC-TN analyzer (Shimadzu Corp., Kyoto, Japan), after filtering through $0.45 \mu \mathrm{m}$ filter papers. The total soil $\mathrm{N}$ was determined in samples after digestion with $\mathrm{H}_{2} \mathrm{SO}_{4}$ at $280{ }^{\circ} \mathrm{C}$ for $2 \mathrm{~h}$ and then determined as described above. The total soil organic carbon was determined by a TOC/TN Analyzer at a temperature of $1100{ }^{\circ} \mathrm{C}$. Water soluble nutrients were measured in the leachates. Samples were analyzed for $\mathrm{K}, \mathrm{Ca}, \mathrm{Na}$, $\mathrm{Mg}, \mathrm{Cu}, \mathrm{Zn}, \mathrm{P}, \mathrm{Mn}, \mathrm{Fe}$, and Mo by inductively coupled Plasma-Mass Spectrometry (ICP-MS, Agilent, 7500a,) accordingly (Muhammad et al., 2016) .

The ammonium acetate-extractable elements were determined according to the method of Rafiq et al. (2014). Soil samples (3 g on an oven-dry basis) were shaken with $30 \mathrm{~mL}$ of $1 \mathrm{~mol} \mathrm{~L}^{-1}$ ammonium acetate ( $\mathrm{pH}$ $7.0)$ at $25{ }^{\circ} \mathrm{C}$ for $2 \mathrm{~h}(200 \mathrm{rev})$. The suspensions were centrifuged at $8000 \mathrm{~g}$ for 10 minutes, filtered through $0.45 \mu \mathrm{m}$ filter papers, and then final volumes adjusted to $30 \mathrm{~mL}$. For the analysis of total elements in biochar, rice straw and grains (at harvest) were milled $<0.2$ $\mathrm{mm}$ using an agate mill. Then $0.2 \mathrm{~g}$ of each (milled) sample was weighed into $50 \mathrm{ml}$ Teflon tubes and digested with $5 \mathrm{ml} \mathrm{HNO}$ (75\%), $1 \mathrm{~mL} \mathrm{HClO}_{4}$ (72\%) and $1 \mathrm{~mL} \mathrm{HF}(40 \%)$ at $100{ }^{\circ} \mathrm{C}$ for $6 \mathrm{~h}$. The digested samples were filtered $(0.45 \mu \mathrm{m})$ and the final volumes adjusted to $30 \mathrm{~mL}$. These samples (ammonium acetate extractable and total elements) were analyzed for K, $\mathrm{Ca}, \mathrm{Na}, \mathrm{Mg}, \mathrm{Cu}, \mathrm{Zn}, \mathrm{P}, \mathrm{Mn}, \mathrm{Fe}$, and Mo by inductively coupled Plasma-Mass Spectrometry (ICP-MS, Agilent, 7500a,). The same procedure without samples served as a control and each measurement was the mean of three replicate analyses. Quality assurance and control for elements in soil, rice grain and rice straw were obtained by determining the above elemental concentrations in standard reference materials (soil GSBZ 50013-88 and rice NCSZC 73008 respectively), approved by General Administration of Quality Supervision, Inspection and Quarantine of the People's Republic of China (AQSIQ). Analytical results were satisfactory, ranging from 96.5 to $101.2 \%$ of given standard concentrations.

Microbial PLFAs were extracted from soil samples collected from the pots at harvest. The PLFAs were extracted from $3.0 \mathrm{~g}$ of freeze-dried soil, fractionated and methylated (Wu et al., 2009b). The detailed method was as described by Muhammad et al. (2014) and the resulting methyl esters were identified by a Gas Chromatograph (N6890, Agilent) fitted with an MIDI SHERLOCKS microbial identification system (version 4.5, MIDI). For each sample the concentrations of individual fatty acid methyl esters were given as mol \% of total PLFAs. The taxonomy used for fatty acids was as carbon atoms (:) double bonds in fatty acid chain and double bond position as (0) from the methyl site of the molecule. The $\mathrm{c}$ and $t$ indicated the geometry (Cis and Trans) of the molecules as suffixes. The a and i prefixes indicated the anteiso and iso branching in the molecule, while methyl groups and positions from the carboxyl end of the molecule were represented as $10 \mathrm{Me}$. The position of hydroxyl $(\mathrm{OH})$ groups and cyclopropane fatty acids (cy) are as described by Muhammad et al. (2014). 


\subsection{Data analysis}

Average 3 replicates of each sample were used in all. Average and stranded deviation were calculated by Microsoft office excel vr.7. Statistical analysis of the data was performed with SPSS 16. All results were presented at significance of $p<0.05$.

\section{Results}

\subsection{Characterization of wheat straw biochar and soils}

The Psammaquent has 58\% sand, 26\% silt and 16\% clay and the Plinthudult had 28\% sand, 50\% silt and $22 \%$ clay as described in USDA classification system. According to Chinese soil taxonomic system such soil are called Red Earth (Wu et al., 2009b). The chemical properties of the biochar and soils used in this study are presented in Table 1 . The $\mathrm{pH}$ of biochar was 10.6. The DOC and DON concentrations were 140 and $35 \mathrm{mg} \mathrm{kg}^{-1}$, respectively. The total organic nitrogen (TON) and TOC in the biochar were $4210 \mathrm{mg} \mathrm{kg}^{-1}$ and $720 \mathrm{~g} \mathrm{~kg}^{-1}$, respectively. The $\mathrm{pH}$ of Psammaquent and Plinthudult was 4.3 and 4.7, respectively. The total organic nitrogen and carbon in the Psammaquent were $38.8 \mathrm{mg} \mathrm{kg}^{-1}$ and 4.0 $\mathrm{g} \mathrm{kg}^{-1}$ and it was $80 \mathrm{mg} \mathrm{kg}{ }^{-1}$ and $6.8 \mathrm{~g} \mathrm{~kg}^{-1}$ in the Plinthudult, respectively. The concentrations of water soluble fractions of micro and macro nutrients with the exceptions of $\mathrm{Na}, \mathrm{B}$, and Mo in the biochar were less than the ammonium acetate extractable and total concentrations.

Table 1. Some properties and ammonium extractable nutrients of the two soils and wheat straw biochar.

\begin{tabular}{|c|c|c|c|c|c|}
\hline Properties & Psammaquent & Plinthudult & \multicolumn{3}{|l|}{ Biochar } \\
\hline$\overline{\text { Clay } \%}$ & 16 & 22 & & & \\
\hline Silt \% & 26 & 50 & \multicolumn{3}{|l|}{-} \\
\hline Sand $\%$ & 58 & 28 & \multicolumn{3}{|l|}{-} \\
\hline $\mathrm{pH}$ & 4.3 & 4.7 & \multicolumn{3}{|l|}{10.60} \\
\hline $\operatorname{DOC}\left(\mathrm{mg} \mathrm{kg}^{-1}\right)$ & 1.1 & 11.1 & \multicolumn{3}{|l|}{140.06} \\
\hline $\operatorname{DON}\left(\mathrm{mgkg}^{-1}\right)$ & 8.35 & 10.8 & \multicolumn{3}{|l|}{35.1} \\
\hline $\mathrm{Ct}\left(\mathrm{g} \mathrm{kg}^{-1}\right)$ & 4.0 & 6.8 & \multicolumn{3}{|l|}{720.05} \\
\hline $\mathrm{Nt}\left(\mathrm{mg} \mathrm{kg}^{-1}\right)$ & 38.8 & 80.1 & \multicolumn{3}{|l|}{4210} \\
\hline \multirow{2}{*}{\multicolumn{4}{|c|}{ Ammonium acetate extractable nutrients }} & \multicolumn{2}{|c|}{ Biochar } \\
\hline & & & & $\mathrm{H}_{2} \mathrm{O}$ Soluble & Total element \\
\hline $\mathrm{Ca}\left(\mathrm{mgkg}^{-1}\right)$ & $365.42 \pm 40.8$ & $976.0 \pm 62.4$ & 1153 & 10.83 & 1572 \\
\hline $\mathrm{K}\left(\mathrm{mgkg}^{-1}\right)$ & $153.25 \pm 12.0$ & $120.8 \pm 5.0$ & 4016 & 3234 & 28350 \\
\hline $\operatorname{Mg}\left(\mathrm{mgkg}^{-1}\right)$ & $184.78 \pm 3.25$ & $164.6 \pm 7.30$ & 91.22 & 2.0 & 9315 \\
\hline $\mathrm{P}\left(\mathrm{mgkg}^{-1}\right)$ & $1.4 \pm 0.02$ & $2.7 \pm 0.14$ & 28.59 & 9.38 & 126.65 \\
\hline $\mathrm{B}\left(\mathrm{mgkg}^{-1}\right)$ & $53.9 \pm 0.25$ & $36.87 \pm 1.25$ & 0.09 & 9.66 & 284.4 \\
\hline $\mathrm{Cu}\left(\mathrm{mgkg}^{-1}\right)$ & $0.38 \pm 0.0$ & $0.24 \pm 0.00$ & 0.06 & 0.01 & 35.94 \\
\hline $\mathrm{Fe}\left(\mathrm{mgkg}^{-1}\right)$ & $0.92 \pm 0.0$ & $1.56 \pm 0.0$ & 0.42 & 0.3 & 2184.5 \\
\hline $\operatorname{Mn}\left(\mathrm{mgkg}^{-1}\right)$ & $98.28 \pm 3.6$ & $92.57 \pm 0.85$ & 1.21 & 0.07 & 379.05 \\
\hline $\operatorname{Mo}\left(\mathrm{mgkg}^{-1}\right)$ & $0.32 \pm 0.0$ & $0.21 \pm 0.00$ & 0.07 & 0.1 & 3.26 \\
\hline $\mathrm{Na}\left(\mathrm{mgkg}^{-1}\right)$ & $9.41 \pm 1.23$ & $29.78 \pm 6.25$ & 275.5 & 2420.7 & 10207.5 \\
\hline $\mathrm{Zn}\left(\mathrm{mgkg}^{-1}\right)$ & $1.37 \pm 0.00$ & $0.46 \pm 0.00$ & 0.05 & 0.07 & 90.71 \\
\hline
\end{tabular}

DOC (Dissolved organic carbon), Ct (Total carbon), Nt (Total nitrogen) 


\subsection{Changes in soil properties due to biochar}

The addition of biochar changed the soil properties such as $\mathrm{pH}$, total exchangeable cations, ammonium acetate extractable nutrients, DOC and DON and total $\mathrm{C}$ and total $\mathrm{N}$. The total exchangeable cation concentrations were significantly higher in biochar amended Psammaquent as compared to the control (Table 1). However, the ammonium acetate extractable nutrient concentration was less in the biochar treated soil than the control. In the Plinthudult, the total exchangeable cation concentrations were significantly increased in biochar treatments compared to the control. The ammonium acetate extractable nutrients were significantly lower in biochar treated soil compared to the control (Table 2). The $\mathrm{pH}$ of the biochar amended Psammaquent and Plinthudult was significantly higher $(6.2 \pm 0.07$ and $6.7 \pm 0.02)$ than the controls $(4.2 \pm 0.06$ and $4.7 \pm 0.21)$, respectively. The biochar amended Psammaquent and Plinthudult contained significantly lower DOC concentrations (40 and 44\%, respectively), than their un-amended counterparts. Beside this DOC concentrations were increased in rice growing soils compared to non-rice growing soils due to plant growth and root proliferation (Table 1,2). The DON concentration was significantly decreased in the biochar treated Psammaquent (24\%) and Plinthudult (15\%) soils as compared to the un-amended soils (Table 2). The DON concentrations were higher in rice growing soils as compared to the control soil concentrations (Table 1,2). The TON concentration in soils was significantly increased in the biochar amended Psammaquent (135\%) and Plinthudult (37\%) as compared to controls and non cultivated soils (Table 1,2)

\subsection{Effect of biochar on nutrient leaching from soils}

The concentrations of water soluble nutrients measured in leachates collected at harvest from the Psammaquent and Plinthudult compared to the controls are given in Table 3. The concentration of $\mathrm{K}, \mathrm{Mg}, \mathrm{B}$ and $\mathrm{Mn}$ in the Psammaquent and the B and $\mathrm{Mn}$ in Plinthudult were significantly decreased in leachates (Table 2,5 ). In contrast, the concentrations of water soluble $\mathrm{Ca}, \mathrm{Fe}$ and $\mathrm{Na}$ in the Psammaquent and $\mathrm{Ca}, \mathrm{K}, \mathrm{Mg}$ and $\mathrm{Na}$ in the. Plinthudult amended with biochar were significantly higher in leachates than the controls (Table 3, 5).

Table 2. Changes in soil properties after addition of $3 \%$ biochar in Psammaquent and Plinthudult in rice cultivation system at harvest.

\begin{tabular}{lllll}
\hline Soil type & Psammaquent-CK & Psammaquent & Plinthudult-CK & Plinthudult +BC \\
\hline $\mathrm{pH}$ & $4.2 \pm 0.06 \mathrm{~b}$ & $6.2 \pm 0.07 \mathrm{a}$ & $4.7 \pm 0.21 \mathrm{~b}$ & $6.7 \pm 0.02 \mathrm{a}$ \\
DOC $\left(\mathrm{mgkg}^{-1}\right)$ & $11.5 \pm 0.07 \mathrm{a}$ & $6.85 \pm 0.11 \mathrm{~b}$ & $46.95 \pm 1.33 \mathrm{a}$ & $25.9 \pm 0.13 \mathrm{~b}$ \\
DON $\left(\mathrm{mgKg}^{-1}\right)$ & $17.35 \pm 0.08 \mathrm{a}$ & $12.9 \pm 0.25 \mathrm{~b}$ & $12.8 \pm 0.29 \mathrm{a}$ & $11.25 \pm 0.04 \mathrm{~b}$ \\
$\mathrm{TN}\left(\mathrm{mgkg}^{-1}\right)$ & $0.57 \pm 0.22 \mathrm{~b}$ & $1.34 \pm 0.31 \mathrm{a}$ & $4.11 \pm 0.26 \mathrm{~b}$ & $5.64 \pm 0.33 \mathrm{a}$ \\
TOC $\left(\mathrm{g} \mathrm{kg}^{-1}\right)$ & $11.02 \pm 1.40 \mathrm{~b}$ & $21.01 \pm 1.4 \mathrm{a}$ & $14.70 \pm 1.03 \mathrm{~b}$ & $26.46 \pm 2.12 \mathrm{a}$ \\
tCations & $675.1 \pm 81 \mathrm{~b}$ & $812.6 \pm 74 \mathrm{a}$ & $821.8 \pm 56 \mathrm{~b}$ & $907.8 \pm 87 \mathrm{a}$ \\
tNutrients & $123 \pm 58 \mathrm{a}$ & $100.1 \pm 65 \mathrm{~b}$ & $118.1 \pm 64 \mathrm{a}$ & $105.8 \pm 73 \mathrm{~b}$ \\
TN in grain $\mathrm{gkg}^{-1}$ & $4.1 \pm 0.26 \mathrm{~b}$ & $4.89 \pm 0.12 \mathrm{a}$ & $4.01 \pm 0.03 \mathrm{~b}$ & $4.98 \pm 0.20 \mathrm{a}$ \\
tPLFAs $\left(\mathrm{nmolg}^{-1}\right)$ & $8.16 \pm 0.84 \mathrm{~b}$ & $13.38 \pm 1.02 \mathrm{a}$ & $10.31 \pm 0.36 \mathrm{a}$ & $4.28 \pm 0.91 \mathrm{~b}$ \\
\hline
\end{tabular}

DOC (Dissolved organic carbon), DON (Dissolved organic nitrogen), TN (Total nitrogen), TOC (Total organic carbon), tCations (Total cations), tNutrients (Total nutrients), tPLFAs (Total PLFA concentration). Lowercase letters indicate significant difference at $\mathrm{p}<0.05$ between biochar treatment and control within single soil. 


\subsection{Extractable nutrients in biochar amended and un- amended soils}

The ammonium acetate extractable concentrations of elements with and without added biochar in both rice growing soils are shown in Table 3 . The percentage extractable concentration changes for $\mathrm{K}, \mathrm{B}, \mathrm{Mn}$, and $\mathrm{Zn}$ in the Psammaquent and K, B and Mn in the Plinthudult treated with biochar indicated a significant decrease in concentrations than in the controls in rice growing soils (Table 3, 5). The percentage concentration increases for $\mathrm{Ca}, \mathrm{Mg}$, and $\mathrm{Na}$ in the Psammaquent and for $\mathrm{Ca}, \mathrm{P}, \mathrm{Mg}$ and $\mathrm{Na}$ extracted from the Plinthudult treated with biochar were significantly higher than in the controls (Table 3, 5). The percentage increases in extractable $\mathrm{Cu}, \mathrm{Mo}, \mathrm{Fe}$ and $\mathrm{Zn}$ concentrations were similar in the biochar treated and untreated Plinthudult.

Table 3. Leaching and ammonium acetate extractable nutrients in biochar amended and un amended Psammaquent and Plinthudult at rice harvest.

\begin{tabular}{|c|c|c|c|c|c|c|c|c|}
\hline $\begin{array}{l}\text { Leac } \\
\text { amer }\end{array}$ & $\begin{array}{l}\text { of nutrients in } \\
\text { soils }\left(\mathrm{mg} \mathrm{kg}^{-1}\right)\end{array}$ & trol and bioch & & & $\begin{array}{l}\text { Extractable nu } \\
\text { amended soils }\end{array}$ & ts in control ar & iochar & \\
\hline & Ps-CK & $\mathrm{Ps}+\mathrm{BC}$ & Pl-CK & & Ps-CK & $\mathrm{Ps}+\mathrm{BC}$ & Pl- CK & $\mathrm{Pl}+\mathrm{BC}$ \\
\hline$\overline{\mathrm{Ca}}$ & $16.35 \pm 1.4 b$ & $17.36 \pm 1.2 \mathrm{a}$ & $22.34 \pm 4.6 b$ & $67.19 \pm 1.3 \mathrm{a}$ & $320.15 \pm 8.8 b$ & $443.70 \pm 9.1 \mathrm{a}$ & $415.1 \pm 2.8 b$ & $535.15 \pm 31.8 \mathrm{a}$ \\
\hline $\mathrm{K}$ & $30.16 \pm 1.9 \mathrm{a}$ & $22.82 \pm 1.26 b$ & $26.74 \pm 2.9 b$ & $48.95 \pm 7.4 \mathrm{a}$ & $194.20 \pm 2 \mathrm{a}$ & $192.45 \pm 0.6 b$ & $342.3 \pm 26.6 \mathrm{a}$ & $273.50 \pm 13.1 b$ \\
\hline $\mathrm{Mg}$ & $6.93 \pm 0.41 \mathrm{a}$ & $6.62 \pm 0.62 b$ & $7.49 \pm 0.70 \mathrm{~b}$ & $10.89 \pm 0.01 \mathrm{a}$ & $153.12 \pm 10.3 b$ & $164.70 \pm 3.7 \mathrm{a}$ & $56.08 \pm 0.4 b$ & $78.97 \pm 4.95 \mathrm{a}$ \\
\hline $\mathrm{P}$ & $1.37 \pm 0.00 \mathrm{a}$ & $1.39 \pm 0.01 \mathrm{a}$ & $1.48 \pm 0.08 \mathrm{a}$ & $1.38 \pm 0.01 \mathrm{a}$ & $4.47 \pm 0.11 \mathrm{a}$ & $4.68 \pm 0.01 \mathrm{a}$ & $4.60 \pm 0.24 b$ & $4.87 \pm 0.01 \mathrm{a}$ \\
\hline B & $20.38 \pm 2.83 a$ & $15.36 \pm 0.52 b$ & $6.05 \pm 0.98 \mathrm{a}$ & $3.87 \pm 0.54 \mathrm{~b}$ & $40.97 \pm 0.15 a$ & $35.42 \pm 0.11 \mathrm{~b}$ & $26.46 \pm 0.07 \mathrm{a}$ & $23.55 \pm 0.11 \mathrm{~b}$ \\
\hline $\mathrm{Cu}$ & $0.05 \pm 0.01 \mathrm{a}$ & $0.01 \pm 0.01 \mathrm{a}$ & $0.05 \pm 0.02 \mathrm{a}$ & $0.02 \pm 0.01 \mathrm{a}$ & $0.11 \pm 0.04 \mathrm{a}$ & $0.06 \pm 0.03 \mathrm{a}$ & $0.14 \pm 0.04 \mathrm{a}$ & $0.12 \pm 0.00 \mathrm{a}$ \\
\hline $\mathrm{Fe}$ & $0.45 \pm 0.07 b$ & $0.74 \pm 0.06 \mathrm{a}$ & $0.42 \pm 0.11 \mathrm{a}$ & $0.57 \pm 0.53 \mathrm{a}$ & $0.78 \pm 0.03 \mathrm{a}$ & $0.82 \pm 0.11 \mathrm{a}$ & $0.81 \pm 0.10 \mathrm{a}$ & $0.80 \pm 0.01 \mathrm{a}$ \\
\hline $\mathrm{Mn}$ & $7.33 \pm 2.32 \mathrm{a}$ & $4.55 \pm 0.65 b$ & $10.88 \pm 0.28 \mathrm{a}$ & $3.31 \pm 0.63 b$ & $75.64 \pm 9.8 \mathrm{a}$ & $58.79 \pm 1.3 b$ & $85.98 \pm 4.95 \mathrm{a}$ & $76.34 \pm 5.73 b$ \\
\hline Mo & $0.03 \pm 0.00 \mathrm{a}$ & $0.03 \pm 0.00 \mathrm{a}$ & $0.03 \pm 0.08 \mathrm{a}$ & $0.03 \pm 0.01 \mathrm{a}$ & $0.23 \pm 0.01 \mathrm{a}$ & $0.08 \pm 0.02 \mathrm{a}$ & $0.11 \pm 0.01 \mathrm{a}$ & $0.06 \pm 0.00 \mathrm{a}$ \\
\hline $\mathrm{Na}$ & $42.29 \pm 1.7 b$ & $60.12 \pm 12.5 a$ & $48.36 \pm 0.17 b$ & $143.58 \pm 6.15 a$ & $7.63 \pm 1.88 b$ & $11.71 \pm 1.81 \mathrm{a}$ & $8.41 \pm 0.30 b$ & $20.18 \pm 0.93 a$ \\
\hline $\mathrm{Zn}$ & $0.03 \pm 0.00 \mathrm{a}$ & $0.02 \pm 0.00 \mathrm{a}$ & $0.06 \pm 0.10 \mathrm{a}$ & $0.01 \pm 0.00 \mathrm{a}$ & $0.79 \pm 0.65 a$ & $0.30 \pm 0.08 b$ & $0.01 \pm 0.06 \mathrm{a}$ & $0.04 \pm 0.06 \mathrm{a}$ \\
\hline
\end{tabular}

Ps (Psammaquent), Pl (Plinthudult), CK (Control), BC (Biochar). Lowercase letters indicate significant difference at $p<0.05$ between biochar treatment and control within single soil.

\subsection{Effect of biochar on plant growth}

The biochar applications significantly increased plant growth and yield in both soils as compared to the control (Figure 1). The plant height (Figure $1 \mathrm{~A}, \mathrm{E}$ ), leaf length (Figure 1 B, F) and grain yield (Figure 1, D, H) were all greater in the biochar amended Psammaquent and Plinthudult as compared to the control, in addition to earlier flowering and maturation (Figure 2). The leaf width was not significantly increased in the biochar amended soils than in the controls. The grain yield in the biochar amended Psammaquent was $15.46 \pm 1.12 \mathrm{~g}$ per pot as compared $11.7 \pm 0.54 \mathrm{~g}$ in the control, which showed a significant increase of $32 \%$. The corresponding values in the Plinthudult were $24.59 \pm 0.96 \mathrm{~g}$ as compared to $17.35 \pm 1.2 \mathrm{~g}$ with a $41 \%$ increase (Table 2 Figure 2). The concentrations of extractable $\mathrm{Ca}$ and $\mathrm{Na}$ in the Psammaquent and $\mathrm{Ca}, \mathrm{Mg}, \mathrm{P}$ and $\mathrm{Na}$ in Plinthudult soil were significantly higher than the control (Table 3, 5). 

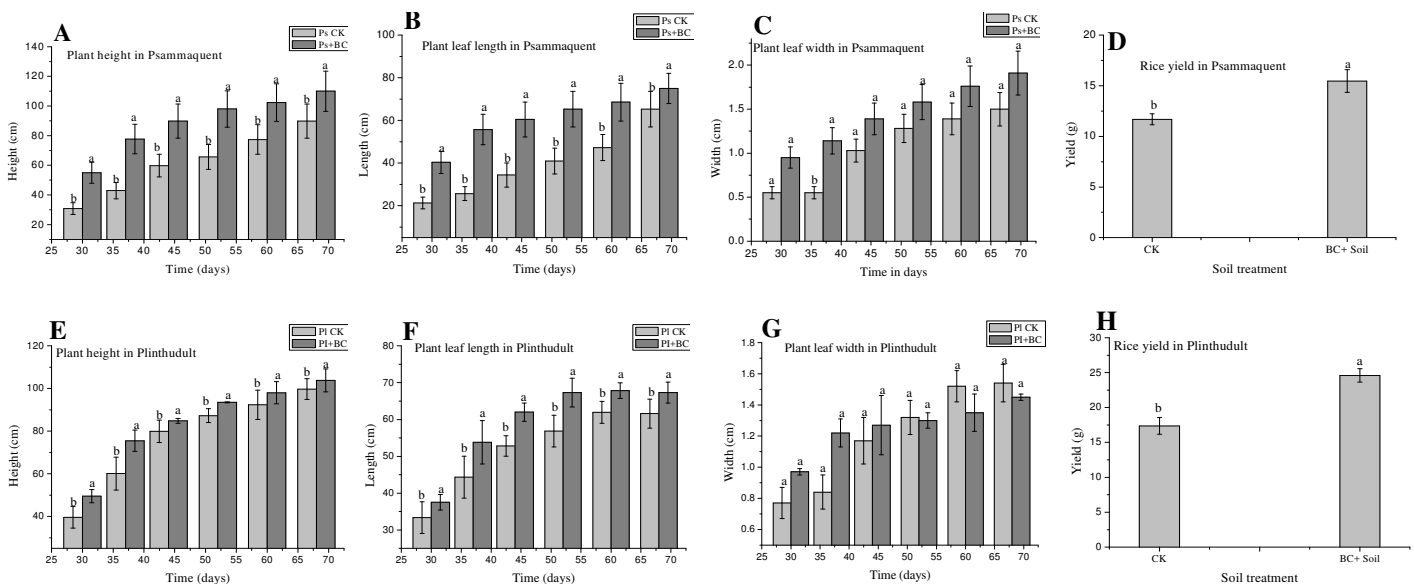

Figure 1. Effect of 3\% wheat straw biochar on rice plant height, leaf length and width and grain yield in Psammaquent (Ps) and Plinthudult (Pl) compared to control soils. CK (control), BC (biochar). Different letters are significat at $(\mathrm{p}<0.05)$.

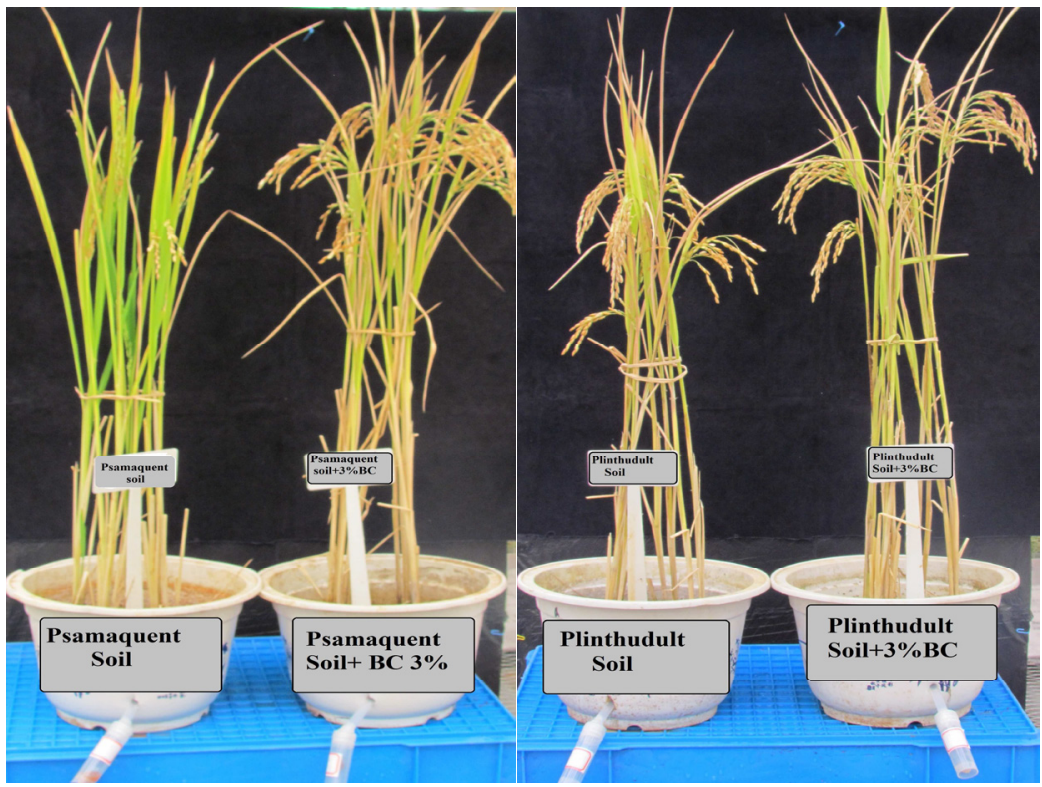

Figure 2. Effect of 3\% biochar on rice plant growth in Psammaquent and Plinthudult 


\subsection{Accumulation of nutrients in rice straw and grain}

The concentration of nutrients in rice straw and grain are given in Table 4. The percentage concentrations of $\mathrm{Ca}, \mathrm{B}, \mathrm{Cu}, \mathrm{Mo}$ and $\mathrm{Fe}$ in rice straw from the biochar amended Psammaquent and $\mathrm{Ca}, \mathrm{K}, \mathrm{Mg}$, $\mathrm{B}, \mathrm{Cu}$ and $\mathrm{Fe}$ in rice straw obtained from the biochar amended Plinthudult were significantly lower than in the controls (Table 4, 5). The percentage concentrations of $\mathrm{K}, \mathrm{Mg}, \mathrm{P}, \mathrm{Mn}, \mathrm{Na}$ and $\mathrm{Zn}$ in rice straw obtained from the Psammaquent and Mn, Mo, Na and $\mathrm{Zn}$ in rice straw obtained from the Plinthudult were significantly higher in the biochar amended than the control soil (Table 4, 5). The concentrations of nutrients measured in rice straw were generally higher than in the rice grains in biochar amended and controls soils. The concentrations of $\mathrm{Ca}, \mathrm{P}, \mathrm{B}$ and $\mathrm{Fe}$ in the Psammaquent and the $\mathrm{Ca}, \mathrm{K}, \mathrm{Mg}, \mathrm{B}, \mathrm{P}, \mathrm{Cu}$ and $\mathrm{Fe}$ in the Plinthudult were significantly lower in rice grains obtained from biochar amended than control soil. The concentrations of $\mathrm{K}, \mathrm{Mg}, \mathrm{Mn}, \mathrm{Na}$ and $\mathrm{Zn}$ in rice grain obtained from the biochar amended Psammaquent and $\mathrm{Mn}, \mathrm{Mo}, \mathrm{Na}$ and $\mathrm{Zn}$ in rice grains obtained from the biochar amended Plinthudult were significantly higher than in the control soils (Table $4,5)$.

Table 4. Concentration of nutrients in rice grains and straw obtained from biochar amended and unamended Psammaquent and Plinthudult at harvest

\begin{tabular}{lll|ll|ll|ll}
\hline \multicolumn{4}{l}{ Concentration of nutrients in rice grain $\left(\mathrm{mg} \mathrm{kg}^{-1}\right)$} & \multicolumn{4}{l}{ Concentration of nutrients in rice straw $\left(\mathrm{mg} \mathrm{kg}^{-1}\right)$} \\
\hline $\mathrm{Ca}$ & Ps-CK & Ps $+\mathrm{BC}$ & $\mathrm{Pl}-\mathrm{CK}$ & $\mathrm{Pl}+\mathrm{BC}$ & Ps-CK & Ps+BC & Pl-CK & Pl $+\mathrm{BC}$ \\
$\mathrm{K}$ & $2703 \mathrm{~b} \pm 11.6 \mathrm{a}$ & $3149.6 \pm 27.9 \mathrm{a}$ & $3195 \pm 26.8 \mathrm{a}$ & $3073 \pm 22.6 \mathrm{~b}$ & $19681.7 \pm 19.5 \mathrm{~b}$ & $20694.8 \pm 30 . \mathrm{a}$ & $20722 \pm 71.9 \mathrm{a}$ & $19972 \pm 25.5 \mathrm{~b}$ \\
$\mathrm{Mg}$ & $1381.1 \pm 227.8 \mathrm{~b}$ & $5551.6 \pm 761.9 \mathrm{a}$ & $1698 \pm 150 \mathrm{a}$ & $1682.6 \pm 231 \mathrm{~b}$ & $7381.23 \pm 15.5 \mathrm{~b}$ & $10470.5 \pm 75.1 \mathrm{a}$ & $9348.20 \pm 89.5 \mathrm{a}$ & $9062.12 \pm 35 \mathrm{~b}$ \\
$\mathrm{P}$ & $5.09 \pm 0.76 \mathrm{a}$ & $4.48 \pm 0.19 \mathrm{~b}$ & $5.53 \pm 0.01 \mathrm{a}$ & $5.20 \pm 00 \mathrm{~b}$ & $1.50 \pm 0.15 \mathrm{~b}$ & $1.76 \pm 0.16 \mathrm{a}$ & $1.39 \pm 0.20 \mathrm{a}$ & $1.35 \pm 0.13 \mathrm{a}$ \\
$\mathrm{B}$ & $7.38 \pm 0.02 \mathrm{a}$ & $6.29 \pm 0.01 \mathrm{~b}$ & $8.35 \pm 0.02 \mathrm{a}$ & $6.19 \pm 0.01 \mathrm{~b}$ & $7.6 \pm 0.01 \mathrm{a}$ & $6.4 \pm 0.00 \mathrm{~b}$ & $7.47 \pm 0.02 \mathrm{a}$ & $6.39 \pm 0.01 \mathrm{~b}$ \\
$\mathrm{Cu}$ & $9.90 \pm 0.09 \mathrm{a}$ & $9.80 \pm 0.14 \mathrm{a}$ & $5.49 \pm 0.22 \mathrm{a}$ & $4.74 \pm 0.10 \mathrm{~b}$ & $22.23 \pm 1.6 \mathrm{a}$ & $19.32 \pm 0.2 \mathrm{~b}$ & $12.54 \pm 0.21 \mathrm{a}$ & $8.69 \pm 0.03 \mathrm{~b}$ \\
$\mathrm{Fe}$ & $44.46 \pm 29.60 \mathrm{a}$ & $40.45 \pm 2.84 \mathrm{~b}$ & $35.54 \pm 3.29 \mathrm{a}$ & $30.74 \pm 2.82 \mathrm{~b}$ & $970.4 \pm 60 \mathrm{a}$ & $448.10 \pm 1.8 \mathrm{~b}$ & $480.47 \pm 4.22 \mathrm{a}$ & $353.07 \pm 1.1 \mathrm{~b}$ \\
$\mathrm{Mn}$ & $86.93 \pm 3.42 \mathrm{~b}$ & $97.90 \pm 2.49 \mathrm{a}$ & $81.72 \pm 1.39 \mathrm{~b}$ & $89.71 \pm 3.63 \mathrm{a}$ & $3790.2 \pm 75.0 \mathrm{~b}$ & $4570.7 \pm 80.2 \mathrm{a}$ & $2986 \pm 21.5 \mathrm{~b}$ & $4593.3 \pm 83.6 \mathrm{a}$ \\
$\mathrm{Mo}$ & $0.09 \pm 0.04 \mathrm{a}$ & $0.08 \pm 0.03 \mathrm{a}$ & $0.42 \pm 0.02 \mathrm{~b}$ & $0.71 \pm 0.03 \mathrm{a}$ & $0.31 \pm 0.03 \mathrm{a}$ & $0.02 \pm 0.01 \mathrm{~b}$ & $0.13 \pm 0.04 \mathrm{~b}$ & $0.39 \pm 0.27 \mathrm{a}$ \\
$\mathrm{Na}$ & $492.46 \pm 45.6 \mathrm{~b}$ & $588.64 \pm 40.1 \mathrm{a}$ & $243.03 \pm 54.6 \mathrm{~b}$ & $3335.7 \pm 43 \mathrm{a}$ & $1644.7 \pm 47.2 \mathrm{~b}$ & $1998.5 \pm 36.8 \mathrm{a}$ & $2730.5 \pm 44.8 \mathrm{~b}$ & $3420.2 \pm 32 \mathrm{a}$ \\
$\mathrm{Zn}$ & $44.94 \pm 1.35 \mathrm{~b}$ & $45.70 \pm 3.41 \mathrm{a}$ & $54.07 \pm 3.00 \mathrm{~b}$ & $72.32 \pm 9.17 \mathrm{a}$ & $103.88 \pm 2.4 \mathrm{~b}$ & $211.46 \pm 0.3 \mathrm{a}$ & $74.35 \pm 1.38 \mathrm{~b}$ & $131.76 \pm 0.79 \mathrm{a}$ \\
\hline
\end{tabular}

Ps (Psammaquent), Pl (Plinthudult), CK (Control), BC (Biochar). Lowercase letters indicate significant difference at $p<0.05$ between biochar treatment and control within single soil. 
Table 5. Percentage concentration (+) increased and (-) decreased in soil leachates, extractions, rice grains and straw obtained from biochar added soils compared to controls at rice harvest

\begin{tabular}{|c|c|c|c|c|c|c|c|c|}
\hline \multicolumn{3}{|c|}{$\begin{array}{l}\text { Percent change of nutrients } \\
\text { in leachates }\end{array}$} & \multicolumn{2}{|c|}{$\begin{array}{l}\text { Percent change in } \\
\text { extractable nutrients }\end{array}$} & \multicolumn{2}{|c|}{$\begin{array}{l}\text { Percent change of } \\
\text { nutrients in rice grain }\end{array}$} & \multicolumn{2}{|c|}{$\begin{array}{l}\text { Percent change of } \\
\text { nutrients in rice straw }\end{array}$} \\
\hline & Ps & $\mathrm{Pl}$ & Ps & $\mathrm{Pl}$ & Ps & $\mathrm{Pl}$ & Ps & $\mathrm{Pl}$ \\
\hline $\mathrm{Ca}$ & +6.17 & +200.00 & +38.60 & +28.93 & -20.98 & -28.54 & -15.66 & -12.11 \\
\hline K & -24.33 & +83.05 & -1.00 & -20.102 & +16.54 & -3.80 & +5.14 & -3.61 \\
\hline $\mathrm{Mg}$ & -4.47 & +212.03 & +7.56 & +40.81 & +301.99 & -1.0 & +41.85 & -3.05 \\
\hline $\mathrm{P}$ & +1.45 & -6.75 & +4.70 & +5.87 & -11.98 & -5.96 & +17.33 & -2.87 \\
\hline B & -24.63 & -50.03 & -13.57 & -11.01 & -14.76 & -25.86 & -15.78 & -14.45 \\
\hline $\mathrm{Cu}$ & -80.00 & -60.0 & -45.45 & -33.33 & -1.0 & -13.01 & -13.09 & -30.70 \\
\hline $\mathrm{Fe}$ & +64.44 & +43.71 & +5.128 & 00 & -9.01 & -13.50 & -53.81 & -26.45 \\
\hline $\mathrm{Mn}$ & -37.92 & -69.58 & -22.28 & -11.21 & +12.61 & +9.78 & +20.58 & +53.86 \\
\hline Mo & 00 & 0.00 & -65.21 & -45.45 & -11.11 & +69.04 & -93.54 & +200 \\
\hline $\mathrm{Na}$ & +42.16 & +196.99 & +53.73 & +150.96 & +19.55 & +37.86 & +21.53 & +25.27 \\
\hline $\mathrm{Zn}$ & -33.33 & -83.33 & -62.02 & +300 & -1.70 & +33.75 & +104.85 & +77.02 \\
\hline
\end{tabular}

Ps (Psammaquent), Pl (Plinthudult)

\subsection{Microbial PLFA community structure in biochar amended soils growing rice}

The different microbial community structures, as measured by PLFA profiles, determined in soil samples collected at harvest from biochar amended and non-amended Psammaquent and Plinthudult are shown in Figure 3. The total PLFA concentration was significantly higher in the biochar amended Psammaquent than the control and it was significantly reduced in the biochar amended Plinthudult than the un-amended counterpart (Table 2). The concentration of total bacterial PLFA was significantly increased in the biochar amended Plinthudult as compared to the control.

The protozoa and fungal PLFA concentrations were significantly reduced in the biochar treated Plinthudult compared to the control (Figure 3C). The total bacterial PLFA concentration was significantly decreased in the biochar amended Psammaquent than the control soil. The protozoa and fungal PLFA concentrations were significantly higher in the biochar treated Psammaquent than in the control soil (Figure 3D). In addition, the concentrations of branching (a14:0, a16:0), hydroxy (16N alcohol), Gram +ve bacterial (a15:0, a17:0) (Bossio et al., 1998), protozoa (18:3w6c) and saprophytic fungal $(18: 2 w 6,9 \mathrm{c})$ PLFAs (Kozdroj and van Elsas, $2001)$, in the Psammaquent and hydroxy (16:0N alcohol), Gram +ve bacterial (i17:0) and saprophytic fungal (18:1w9c) PLFAs in the Plinthudult were significantly higher in the biochar treated soil at harvest, compared to the control. The concentrations of actinomycete (10 Me16:0), saturated (16:0), arbuscular mycorrhizal (16:1w5c), Gram+ve bacterial (i17:0), saprophytic fungal $(18: 1 \mathrm{w} 9 \mathrm{c})$, anaerobic bacterial (cy19:0) and actinomycete (10 Me 19:0) PLFAs in the Psammaquent and the branching PLFAs (a14:0, a16:0), Gram +ve bacterial (a15:0, a17:0), saturated (16:0), protozoal (18:3w6c) and cy19:0 PLFAs in the Plinthudult were significantly higher than in the biochar amended soils. 

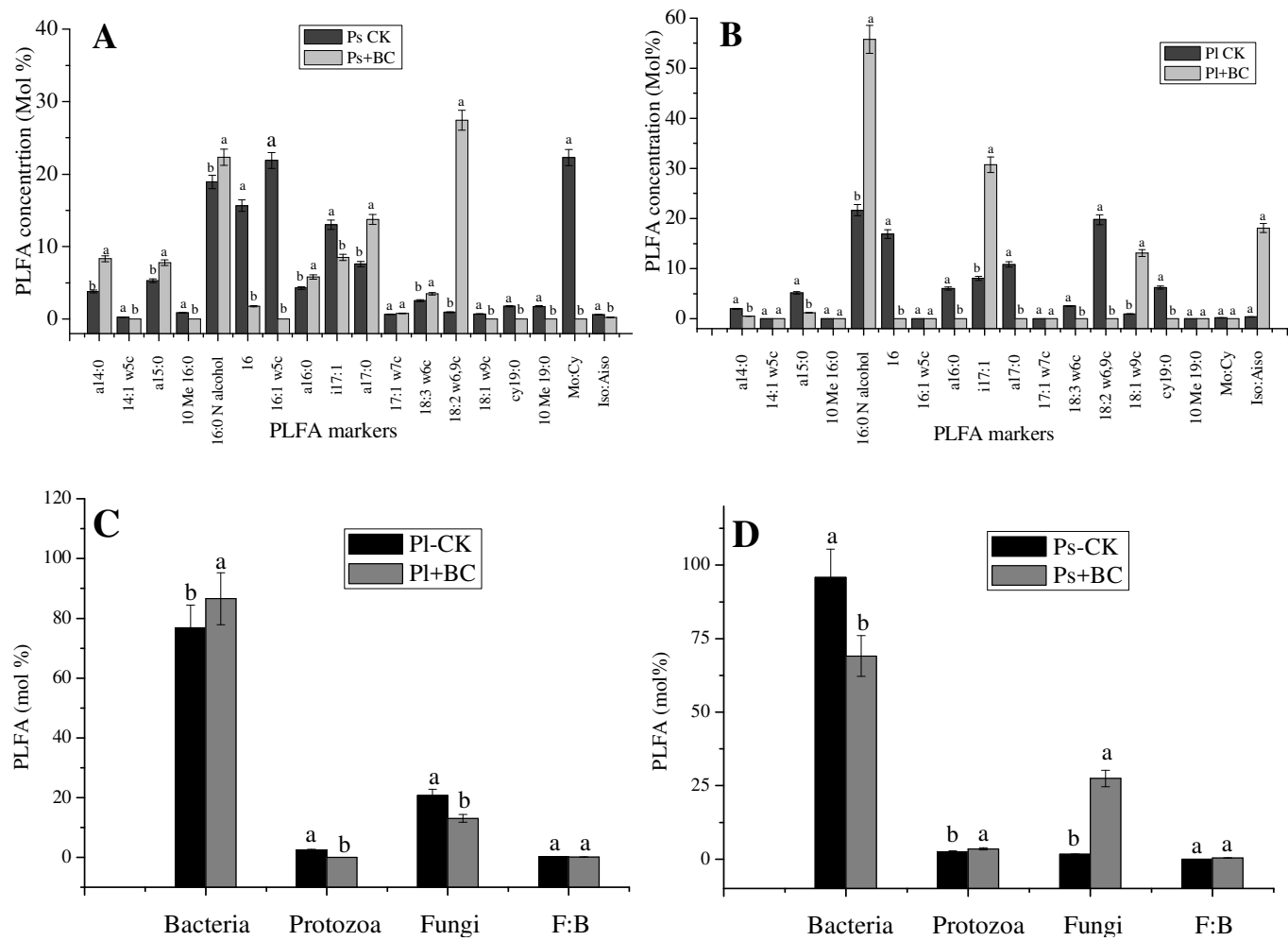

Figure 3. PLFA pattern (mol \%) in 3\% biochar amended and unamended (A) Psammaquent and (B) Plinthudult. Microbial community structure in (C) Plinthudult and (D) Psammaquent in rice cultivation system at harvest, Different letters are significat at ( $p<0.05$ ). Ps (Psammaquent), Pl (Plinthudult), CK (Control), BC (Biochar), F:B ( fungi:bacteria).

\section{Discussion}

\subsection{Changes in soils properties due to biochar}

The wheat straw biochar increased exchangeable cationic content in soils growing rice due to its higher concentration in biochar consequently it increased the soil $\mathrm{pH}$ at harvest. Besides this, the reduced concentration of nutrients in biochar amended soils at harvest are due to the higher accumulation of nutrients at higher yield and immobilization on biochar surfaces (Hammer et al., 2014) as well as lower concentration of theses nutrients in soils and biochar. The lower DOC and DON concentrations in the biochar amended Psammaquent and Plinthudult might be due to the lesser microbial mineralization of organic matter under continuous flooded and water logged conditions, coupled with increased $\mathrm{N}$ adsorption on biochar surfaces. The increased $\mathrm{N}$ concentration in the biochar amended and control than uncultivated soils was due to the accumulation of applied $\mathrm{N}$ by organic matter and adsorption onto biochar surfaces, as reported previously (Liu et al., 2013). However, the increased $\mathrm{N}$ concentration in biochar amended soils than controls is an indicator of improved soil fertility and reduced environmental losses of $\mathrm{N}$ due to its sequestration in 
soils. The results of this study revealed that biochar addition to both soils significantly reduced the DOC in the leachates and increased total $\mathrm{C}$ in both soils at harvest compared to controls and native soils. It indicates that biochar addition to both soils reduced $\mathrm{C}$ loss from soil and increased $\mathrm{C}$ sequestration in soils. The increased total $\mathrm{C}$ and total $\mathrm{N}$ in soils are also positive indicators of improved soil fertility. Generally increased soil carbon could increase microbial growth and its mineralization leading to increased nutrient availability in soils (Warnock et al., 2007). Thus, the increased $\mathrm{C}$ and nitrogen availability can increase the plant growth in soils amended with biochar. Furthermore, the obtained results indicated that water logged conditions in rice growing soil generate anaerobic environment and reduce the mineralization rate by limiting the microbial population and their growth as earlier studies indicated (Zhou et al., 2014).

\subsection{Leaching of Nutrients from biochar amended soils}

The decreased concentration of nutrients in biochar added soils as compared to the control indicated that biochar addition to soils significantly decreases these nutrient concentrations in leachates. However, the nutrients leached from biochar amended and control soils may be due to higher amount of nutrients in soils and biochar (Table 1) and less accumulation of these nutrients in the soil organic matter. In addition, the precipitation/fixation of elements due to increase soil $\mathrm{pH}$ (Shen et al., 2016) can also reduce the nutrient leaching. The soil texture changed by biochar and water logged condition also influence the leaching of elements from these soils. The decrease in the water soluble nutrients in leachates from both biochar amended soils therefore indicates that biochar addition significantly increases the retention of these nutrients, so increasing their availability. Furthermore, the decreased nutrient concentrations in leachates of both biochar amended soils can be attributed to the increased total $\mathrm{C}$ and total $\mathrm{N}$ and decreased DOC and DON in both biochar amended soils. The increased organic matter in biochar amended soil immobilizes more nutrients and decreases leaching (Khan et al., 2013). However, biochar addition to both the Psammaquent and Plinthudult reduced the leaching of nutrients and increased their concentrations in soils under rice. The greater loss of $\mathrm{Mg}$ and other nutrients in the leachates is increased by their inherent property of being mostly soluble and exchangeable ions. It also may be due to the higher clay, silt and native organic carbon in the Plinthudult. Furthermore, $\mathrm{Mg}$ and $\mathrm{K}$ may be could not accumulate as these were higher in biochar (Muhammad et al., 2016). However, the psammaquent has lesser native organic carbon and it was increased after cultivation and biochar addition that led to greater accumulation and aggregation, consequently fixing most of the elements. Similar mechanisms are probably involved in the leaching of $\mathrm{Ca}$, $\mathrm{Na}$ and Fe. Where excessive amounts of elements are leached in water, it indicates that biochars containing higher amount of elements upon application to soils release excessive amount of elements in water. The smaller percentage concentrations of nutrients in the biochar amended Psammaquent and Plinthudult than in the un-amended soils at rice harvest is attributed to increased nutrient accumulation, due to higher yields in the biochar amended soils compared to controls. Other types of biochar have also produced major decreases in available soil nutrients for the same reasons (Ahmad et al., 2012; Khan et al., 2013; Uchimiya et al., 2011; Zheng et al., 2012). This process has also been examined by kinetic and adsorption experiments (Khan et al., 2013; Kołodyńska et al., 2012) and the soil $\mathrm{pH}$ within this range has been related to increased adsorption and precipitation of soluble nutrients and other elements (Khan et al., 2013; Kołodyńska et al., 
2012). Therefore, in this work the decreased percentage of extractable concentrations of K of $1 \%$ and $20 \%$ in the Psammaquent and Plinthudult respectively were attributed to increased $\mathrm{pH}$ and $\mathrm{K}$ fixation by clay minerals as previously reported (Jiyun, 1996; Zhao et al., 2014). Another possible reason for this may be more accumulation of $\mathrm{K}$ in growing crop, resulting in decrease extractable concentrations.

\subsection{Effect of biochar on plant growth and nutrient accumulation}

Plant growth and yields were significantly higher in biochar added soils as compared to the control. This indicates that these elements were readily available for plant, which may be the reason for the increased crop growth and yield. Furthermore, increased grain yield and plant heights in biochar amended soils also showed that biochar significantly increased the crop growth and yield. Increase in soil $\mathrm{pH}$ to 6.2 and 6.7 may also increases the availability of various nutrients to plants in biochar amended soils compared to the controls and inherent soils as indicated in this study. Biochar increased the soil $\mathrm{pH}$, consequently extractable nutrients increased and leaching and water soluble nutrients were decreased. These results suggest that nutrient retention in biochar amended soils and increased crop yield are an indicator of soil improvement and crop yield. Furthermore, the decreased accumulation of nutrients following biochar addition to both soils under rice cultivation, several explanatory mechanisms have been proposed, some of them in accord with our results. The simplest mechanism is that the increase in soil $\mathrm{pH}$, exchangeable cations, organic matter and changed soil densities increases the sorption of nutrients in soil as well as increasing the chelation and fixation of nutrients by soil organic matter (Khan et al., 2013; Kim et al., 2013; Kookana et al., 2011; Zheng et al., 2012). The anaerobic environment due to water logged conditions in soils growing rice might influence nutrient accumulation and plant health.

\subsection{Microbial community pattern in biochar added soils}

The results of this study indicated that there were lower microbial PLFA concentrations in both rice cultivated soils, with and without biochar addition, as compared to previous results with both the soils (Dai et al., 2014; Muhammad et al., 2014). This may be due to the, mainly, anaerobic conditions caused by the continuous waterlogged conditions in rice growing soils. Therefore aerobic microbial communities are unable to survive there. Short periods of aeration may not permit much, if any, growth of aerobic microbial communities. Discrete aerobic and anaerobic periods may be unsuitable for significant microbial establishment during rice growth. However, the Psammaquent contained higher concentrations of PLFAs than the Plinthudult, which are typically poor in nutrients and soil organic matter and may contain only extremophiles (Ahn et al., 2012). Changes in factors such as water, $\mathrm{pH}$ and organic matter increased the development of selective microbial communities which are adapted to newly established environments. The biochar addition to Psammaquent increased the growth of saprophytic fungi, protozoa, sulfate reducing $b a$ cillus spp. and Gram +ve bacteria, all measured as PLFAs. All these PLFAs are indicative of microbial communities existing in comparatively extreme environments. For example, waterlogged soil under rice and the addition of organic matter provides increased nutrients for the microbial population. The higher ratios of Mo:Cy PLFAs in un-amended soil indicates that increased nutritional stress in the microbial communities (Muhammad et al., 2014), which is overcome in biochar amended soils. The saprophytic fungi 
and Gram +ve bacteria were the only microbial communities that developed in the Plinthudult while other microbial communities were undetectable in this biochar amended soil at harvest. Thus, soil growing rice is an extreme environment for microbial communities and the addition of biochar increases soil anaerobicity due to water filled soil pores which produce an even more extreme anaerobic environment. The increased concentration of iso:anteiso PLFAs in the biochar amended soils growing rice indicates that biochar addition coupled with water logging in the soil increased environmental stress in microbial communities. The biochar addition increased the intensity of anaerobiosis in soils which eliminated most bacterial communities except saprophytic fungi and $\mathrm{G}+\mathrm{ve}$ bacteria (these might be spore formers or anaerobes) in the Plinthudult. It indicates that anaerobic environments can affect both the cycling of organic matter in soils and plant growth. Further investigations are required to explore the exact mechanism(s) involved and the potential benefits of biochar application to different cropping systems in different environmental zones.

\section{Conclusion}

Wheat straw biochar application to rice growing Psammaquent and Plinthudult increased the yield of rice and in contrast it decreased the leaching of nutrients, organic carbon and nitrogen. However, $\mathrm{Ca}, \mathrm{Na}$ and $\mathrm{Mg}$ leaching was increased from biochar added rice growing soils due to higher concentration of these elements in biochar. The biochar also significantly increased the $\mathrm{pH}$, TOC and nitrogen in both soils. Furthermore, the biochar application to soils changed the microbial community pattern by altering the soil properties. Thus, wheat straw biochar can increase the productivity of rice by retaining the soil nutrient coupled with carbon sequestration in the Plinthudult and Psammaquent.

\section{Acknowledgement}

This work was financially supported by the National Basic Research Program of China (2014CB441002, 2011CB100502), and the Fundamental Research Funds for the Central Universities. The first author also acknowledges Chinese Scholarship Council (CSC) for a PhD scholarship.

\section{References}

Ahmad, M., Lee, S.S., Yang, J.E., Ro, H.M., Lee, Y.H., Ok, Y.S. 2012. Effects of soil dilution and amendments (mussel shell, cow bone, and biochar) on $\mathrm{Pb}$ availability and phytotoxicity in military shooting range soil. Ecotoxicol.Environ Saf. 79, 225-231.

Ahn, J.H., Song, J., Kim, B.Y., Kim, M.S., Joa, J.H., Weon, H.Y. 2012. Characterization of the bacterial and archaeal communities in rice field soils subjected to long-term fertilization practices. Journal of Microbiology. 50, 754-765.

Ameloot, N., De Neve, S., Jegajeevagan, K., Yildiz, G., Buchan, D., Funkuin, Y.N., Prins, W., Bouckaert, L., Sleutel, S. 2013. Short-term $\mathrm{CO}_{2}$ and $\mathrm{N}_{2} \mathrm{O}$ emissions and microbial properties of biochar amended sandy loam soils. Soil Biol. Biochem. 57, 401-410.

Bossio, D., Scow, K., Gunapala, N., Graham, K. 1998. Determinants of soil microbial communities: effects of agricultural management, season, and soil type on phospholipid fatty acid profiles. Microbial Ecology. 36, 1-12.

Bruun, E.W., Ambus, P., Egsgaard, H., HauggaardNielsen, H. 2012. Effects of slow and fast pyrolysis biochar on soil $\mathrm{C}$ and $\mathrm{N}$ turnover dynamics. Soil Biology and Biochemistry. 46, 73-79.

Cao, X., Ma, L., Liang, Y., Gao, B., Harris, W. 2011. Simultaneous immobilization of lead and atrazine in contaminated soils using dairy-manure biochar. Environ. Sci. Technol. 45, 4884-4889. 
Cheng, C.H., Lehmann, J., Thies, J.E., Burton, S.D. 2008. Stability of black carbon in soils across a climatic gradient. J. of Geophys. Res. 113, G02027.

Dai, Z., Wang, Y., Muhammad, N., Yu, X., Xiao, K., Meng, J., Liu, X., Xu, J., Brookes, P.C. 2014. The effects and mechanisms of soil acidity changes, following incorporation of biochars in three soils differing in initial $\mathrm{pH}$. Soil Science Society of America Journal. 78, 1606-1614.

Gul, S., Whalen, J.K., Thomas, B.W., Sachdeva, V., Deng, H. 2015. Physico-chemical properties and microbial responses in biochar-amended soils: mechanisms and future directions. Agriculture, Ecosystems \& Environment. 206, 46-59.

Hammer, E.C., Balogh-Brunstad, Z., Jakobsen, I., Olsson, P.A., Stipp, S.L., Rillig, M.C. 2014. A mycorrhizal fungus grows on biochar and captures phosphorus from its surfaces. Soil Biology and Biochemistry. 77, 252-260.

Huang, M., Yang, L., Qin, H., Jiang, L., Zou, Y. 2013. Quantifying the effect of biochar amendment on soil quality and crop productivity in Chinese rice paddies. Field Crops Research. 154, 172-177.

Jiyun, H.S.J. 1996. Potassium fixation in selected soils from north china. Plant Nutrition and Fertilizing Science. 2, 005.

Junna, S., Bingchen, W., Gang, X., Hongbo, S. 2014. Effects of wheat straw biochar on carbon mineralization and guidance for large-scale soil quality improvement in the coastal wetland. Ecological Engineering. 62, 43-47.

Karami, N., Clemente, R., Moreno-Jiménez, E., Lepp, N.W., Beesley, L. 2011. Efficiency of green waste compost and biochar soil amendments for reducing lead and copper mobility and uptake to ryegrass. Journal of Hazardous Materials. 191, 41-48.
Keith, A., Singh, B., Singh, B.P. 2011. Interactive priming of biochar and labile organic matter mineralization in a smectite-rich soil. Environmental Science and Technology. 45, 9611-9618.

Khan, S., Chao, C., Waqas, M., Arp, H.P.H., Zhu, Y.G. 2013. Sewage sludge biochar influence upon rice (Oryza sativa L) yield, metal bioaccumulation and greenhouse gas emissions from acidic paddy soil. Environmental Science and Technology. 47, 8624-8632.

Kim, P., Johnson, A.M., Essington, M.E., Radosevich, M., Kwon, W.T., Lee, S.H., Rials, T.G., Labbé, N. 2013. Effect of $\mathrm{pH}$ on surface characteristics of switchgrass-derived biochars produced by fast pyrolysis. Chemosphere. 90, 2623-2630.

Kołodyńska, D., Wnętrzak, R., Leahy, J., Hayes, M., Kwapiński, W., Hubicki, Z. 2012. Kinetic and adsorptive characterization of biochar in metal ions removal. Chem. Eng. J 197, 295-305.

Kookana, R., Sarmah, A., Van Zwieten, L., Krull, E., Singh, B. 2011. Biochar Application to Soil: Agronomic and Environmental Benefits and Unintended Consequences. Advances in Agronomy. 112, 103-143.

Kozdroj, J., van Elsas, J.D. 2001. Structural diversity of microorganisms in chemically perturbed soil assessed by molecular and cytochemical approaches. J. Microbiol. Methods. 43, 197-212.

Liu, N., Sun, Z.T., Wu, Z.C., Zhan, X.M., Zhang, K., Zhao, E.F., Han, X.R. 2013. Adsorption characteristics of ammonium nitrogen by biochar from diverse origins in water, Advanced Materials Research. Trans Tech Publ, pp: 305-312.

Meng, J., Wang, L., Liu, X., Wu, J., Brookes, P.C., Xu, J. 2013. Physicochemical properties of biochar produced from aerobically composted swine manure and its potential use as an environmental amendment. Bioresource Technology. 142, 641-646. 
Muhammad, N., Brookes, P., Wu, J. 2016. Addition impact of biochar from different feedstocks on microbial community and available concentrations of elements in a Psammaquent and a Plinthudult. Journal of Soil Science and Plant Nutrition. 16, 137-153.

Muhammad, N., Dai, Z., Xiao, K., Meng, J., Brookes, P.C., Liu, X., Wang, H., Wu, J., Xu, J. 2014. Changes in microbial community structure due to biochars generated from different feedstocks and their relationships with soil chemical properties. Geoderma. 226, 270-278.

Rafiq, M.T., Aziz, R., Yang, X., Xiao, W., Rafiq, M.K., Ali, B., Li, T. 2014. Cadmium phytoavailability to rice (Oryza sativa L.) grown in representative Chinese soils. A model to improve soil environmental quality guidelines for food safety. Ecotoxicology and Environmental Safety. 103, 101-107.

Shen, Q., Hedley, M., Camps Arbestain, M., Kirschbaum, M. 2016. Can biochar increase the bioavailability of phosphorus? Journal of Soil Science and Plant Nutrition. 16, 268-286.

Uchimiya, M., Wartelle, L.H., Klasson, K.T., Fortier, C.A., Lima, I.M. 2011. Influence of pyrolysis temperature on biochar property and function as a heavy metal sorbent in soil. Journal of Agricultural and Food Chemistry. 59, 2501-2510.

Warnock, D.D., Lehmann, J., Kuyper, T.W., Rillig, M.C. 2007. Mycorrhizal responses to biochar in soil - concepts and mechanisms. Plant and Soil. 300, 9-20.

Wu, C.Y., Feng, Y., Shohag, M.J.I., Lu, L.1., Wei, Y.Y., Gao, C., Yang, X.E. 2011. Characterization of $68 \mathrm{Zn}$ uptake, translocation, and accumulation into developing grains and young leaves of high Zn-density rice genotype. Journal of Zhejiang University Science B. 12, 408-418.
Wu, Y., Ding, N., Wang, G., Xu, J., Wu, J., Brookes, P.C. 2009a. Effects of different soil weights, storWu, Y., Ding, N., Wang, G., Xu, J., Wu, J., Brookes, P.C. 2009a. Effects of different soil weights, storage times and extraction methods on soil phospholipid fatty acid analyses. Geoderma. 150, 171-178.

Wu, Y., Ma, B., Zhou, L., Wang, H., Xu, J., Kemmitt, S., Brookes, P.C. 2009b. Changes in the soil microbial community structure with latitude in eastern China, based on phospholipid fatty acid analysis. Applied Soil Ecology. 43, 234-240.

Zhang, A., Cui, L., Pan, G., Li, L., Hussain, Q., Zhang, X., Zheng, J., Crowley, D. 2010. Effect of biochar amendment on yield and methane and nitrous oxide emissions from a rice paddy from Tai Lake plain, China. Agriculture, Ecosystems and Environment. 139, 469-475.

Zhao, X., Wang, J., Wang, S., Xing, G. 2014. Successive straw biochar application as a strategy to sequester carbon and improve fertility: A pot experiment with two rice/wheat rotations in paddy soil. Plant and Soil. 378, 279-294.

Zheng, R.L., Cai, C., Liang, J.H., Huang, Q., Chen, Z., Huang, Y.Z., Arp, H.P.H., Sun, G.X. 2012. The effects of biochars from rice residue on the formation of iron plaque and the accumulation of $\mathrm{Cd}, \mathrm{Zn}, \mathrm{Pb}$, As in rice (Oryza sativa L.) seedlings. Chemosphere. 89, 856-862.

Zhou, W., Lv, T.F., Chen, Y., Westby, A.P., Ren, W.J. 2014. Soil Physicochemical and Biological Properties of Paddy-Upland Rotation: A Review. The Scientific World Journal. 856352, 1-8 